\title{
A comparative study of the coordination of saccharinate (sac), thiosaccharinate (tsac) and benzisothiazolinate (bit) ligands to trans-[ $\left.\mathrm{PdCl}_{2}\left(\mathrm{H}_{2} \mathbf{N B z}\right)_{2}\right]$ : molecular structure of cis-[Pd(bit $\left.)_{2}\left(\mathrm{H}_{2} \mathbf{N B z}\right)_{2}\right]$
}

\author{
Subhi A. Al-Jibori ${ }^{1} \cdot$ Wisam J. Hameed $^{1} \cdot$ Lamaan J. Al-Hayaly $^{2}$ • \\ Christoph Wagner ${ }^{3}$ Graeme Hogarth ${ }^{4}$
}

Received: 2 November 2016/Accepted: 5 December 2016/Published online: 23 December 2016

(c) The Author(s) 2016. This article is published with open access at Springerlink.com

\begin{abstract}
A comparative study of reactions of saccharinate (sac), thiosaccharinate (tsac) and benzisothiozolinate (bit) with trans- $\left[\mathrm{PdCl}_{2}\left(\mathrm{H}_{2} \mathrm{NBz}\right)_{2}\right]$ is reported. While in all cases substitution of both chlorides occurs, product types differ for the three closely related ligands. With sodium saccharinate, trans-[$\left[\mathrm{Pd}(\mathrm{N}-\mathrm{sac})_{2}\left(\mathrm{H}_{2} \mathrm{NBz}\right)_{2}\right]$ results in which the sac ligands are N-bound. A similar N-bound coordination is observed with sodium benzisothiazolinate, but a crystal structure shows that they adopt a mutual cis arrangement in cis$\left[\mathrm{Pd}(\mathrm{N}-\mathrm{bit})_{2}\left(\mathrm{H}_{2} \mathrm{NBz}\right)_{2}\right]$. In contrast, with sodium thiosaccharinate it is proposed that the new ligands adopt an S-bound coordination mode in trans-[Pd(S-tsac $\left.)_{2}\left(\mathrm{H}_{2} \mathrm{NBz}\right)_{2}\right]$.
\end{abstract}

\section{Introduction}

Saccharinate (sac) and thiosaccharinate (tsac) anions (Fig. 1) are versatile poly-functional ligands, shown to adopt a variety of coordination modes, and consequently their coordination chemistry has been widely studied $[1,2]$. Palladium(II) and platinum(II) complexes of these ligands

Subhi A. Al-Jibori

subhi_aljibori@yahoo.com

$\square$ Graeme Hogarth

graeme.hogarth@kcl.ac.uk

1 Department of Chemistry, College of Science, University of Tikrit, Tikrit, Iraq

2 Pharmaceutical Chemistry, College of Pharmacy, Hawler Medical University, Erbil, Iraq

3 Institut für Chemie, Martin-Luther-Universität, HalleWittenberg, Kurt-Mothes-Str. 2, 06120 Halle, Germany

4 Department of Chemistry, King's College London, Britannia House, 7 Trinity Street, London SE1 IDB, UK have been detailed [3-18] with some showing promising biological properties [19-24]. In contrast, the coordination chemistry of the related benzisothiozolinate (bit) anion (Fig. 1), resulting from deprotonation of the acidic imine hydrogen in benzisothiazolinone, remains virtually unexplored; as far as we are aware, there are only two literature reports concerning the coordination chemistry of this ligand $[25,26]$. Griffith and co-workers have reported the synthesis of $c i s-\left[\mathrm{Pd}(\mathrm{N}-b i t)_{2}\left(\kappa^{2}\right.\right.$-en $\left.)\right] \quad(\mathrm{en}=$ ethylenediamine) and $\left[\mathrm{Pt}\left(\mathrm{NH}_{3}\right)_{2}(\mathrm{~N}-\mathrm{bit})_{2}\right]$, the former being characterised by single-crystal X-ray crystallography [25], while we have recently detailed the synthesis of a number of square-planar palladium complexes, trans- $\left[\mathrm{Pd}(\mathrm{N}-\mathrm{bit})_{2} \mathrm{~L}_{2}\right]$, with amine, amide and diphosphine co-ligands [26]. The latter can be formed via two synthetic routes, namely reaction of $\left[\mathrm{Pd}(\mathrm{bit})_{2}\right] . \mathrm{H}_{2} \mathrm{O}$ with neutral ligands or via displacement of both chlorides in trans- $\left[\mathrm{PdCl}_{2} \mathrm{~L}_{2}\right]$. Herein, we develop further the coordination chemistry of the benzisothiozolinate anion in a comparative study of reactions of saccharinate ( $\mathrm{sac}$ ), thiosaccharinate (tsac) and benzisothiazolinate (bit) with trans-[ $\left.\mathrm{PdCl}_{2}\left(\mathrm{H}_{2} \mathrm{NBz}\right)_{2}\right]$. The surprising outcome of this simple study was the isolation of different product types in each case.

\section{Experimental}

\section{General methods}

${ }^{1} \mathrm{H}$ NMR spectra were recorded on a Varian Unity spectrometer in $\mathrm{CDCl}_{3}$ or $d^{6}$-dmso. IR spectra were recorded on a Shimadzu FT-IR 8400 spectrophotometer in the $400-4000 \mathrm{~cm}^{-1}$ range using $\mathrm{KBr}$ discs and in the $200-600 \mathrm{~cm}^{-1}$ using CsI discs. Elemental analysis was carried out at Al Al-Bayt University, Jordan, using a Euro- 


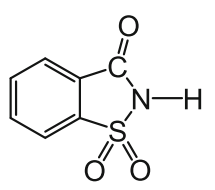

$\mathrm{sacH}$

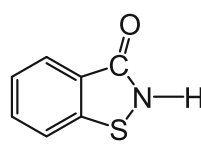

bitH

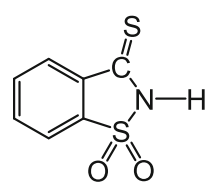

tsacH
Fig. 1 Saccharin $(\mathrm{sacH})$, benzisothiazoline (bitH) and thiosaccharin (tsacH)

vector EURO EA 300 elemental analyzer. Melting points were measured on a Gallenkamp melting point apparatus and are uncorrected. Conductivity measurements were carried out on $10^{-3} \mathrm{M}$ solutions using a digital conductivity meter. $\mathrm{Na}_{2} \mathrm{PdCl}_{4}$, benzisothiazolinone (Hbit), benzylamine and sodium saccharinate were purchased and used as received. Thiosaccharin [27] and trans- $\left[\mathrm{PdCl}_{2}\right.$ $\left(\mathrm{H}_{2} \mathrm{NBz}\right)_{2}$ ] (1) [28] were prepared by literature methods.

\section{Synthesis of 2}

A solution of Nasac $(0.285 \mathrm{~g}, 1.35 \mathrm{mmol})$ in $\mathrm{MeOH}$ $\left(5 \mathrm{~cm}^{3}\right)$ was added to a solution of $1(0.244 \mathrm{~g}, 0.62 \mathrm{mmol})$ in $\mathrm{MeOH}\left(10 \mathrm{~cm}^{3}\right)$. The mixture was stirred at room temperature for $3 \mathrm{~h}$. The resulting yellow solid was collected by filtration, washed with $\mathrm{MeOH}$ and dried in vacuum. It was recrystallised from $\mathrm{CHCl}_{3} / \mathrm{MeOH}$ to afford 2 as a yellow crystalline solid. Yield $0.341 \mathrm{~g}, 73 \%$. Anal. Calc. for $\mathrm{C}_{28} \mathrm{H}_{26} \mathrm{~N}_{4} \mathrm{O}_{6} \mathrm{PdS}_{2}$ : C, 49.1, H, 3.8, N, 8.2. Found: C, 49.2, H, 3.7, N, 8.2. Molar conductivity (DMSO): 0.40 $\left(\Omega^{-1} \mathrm{~mol}^{-1} \mathrm{~cm}^{-1}\right)$. IR (KBr): 3265w, 3130w, 3029w, $1672 \mathrm{~s}, 1593 \mathrm{w}, 1451 \mathrm{w}, 1290 \mathrm{~s}, 1155 \mathrm{~m}, 563 \mathrm{~m} \mathrm{~cm}^{-1} \cdot{ }^{1} \mathrm{H}$ NMR $\left(\mathrm{CDCl}_{3}\right): \delta$ 7.94-7.92 (m, 2H, sac), 7.87-7.85 (m, 2H, sac), 7.75-7.72 (m, 4H, sac), 7.30-7.22 (m, 10H, Ph),

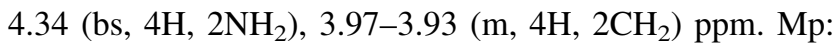
224-226 ${ }^{\circ} \mathrm{C}$.

\section{Synthesis of 3}

A solution of tsac $(0.051 \mathrm{~g}, 0.26 \mathrm{mmol})$ in $\mathrm{MeOH}\left(5 \mathrm{~cm}^{3}\right)$ was added to a solution of $\mathbf{1}(0.051 \mathrm{~g}, 0.13 \mathrm{mmol})$ in $\mathrm{MeOH}\left(10 \mathrm{~cm}^{3}\right)$. The mixture was stirred at $30{ }^{\circ} \mathrm{C}$ for $2 \mathrm{~h}$. The yellow-orange solid formed was collected by filtration and dried under vacuum. Yield $0.068 \mathrm{~g}, 75 \%$. Anal. Calc. for $\mathrm{C}_{28} \mathrm{H}_{26} \mathrm{~N}_{4} \mathrm{O}_{4} \mathrm{PdS}_{4}$ : C, 46.9, H, 3.7, N, 7.8. Found: C, 46.9, H, 3.8, N, 8.0. Molar conductivity (DMSO): 0.40 $\left(\Omega^{-1} \mathrm{~mol}^{-1} \mathrm{~cm}^{-1}\right)$. IR $(\mathrm{KBr}): 3425 \mathrm{sb}, 3051 \mathrm{w}, 2922 \mathrm{w}$, $1541 \mathrm{~m}, 1463 \mathrm{~m}, 1384 \mathrm{~s}, 1163 \mathrm{~s}, 1004 \mathrm{~m}, 806 \mathrm{~m}, 370 \mathrm{~s} \mathrm{~cm}^{-1}$. ${ }^{1} \mathrm{H}$ NMR (DMSO-d ${ }^{6}$ ): $\delta 7.89$ (dd, J 8.0, J 3.2, 4H, tsac), 7.71 (t, J 8.0, 2H, tsac), 7.58 (t, J 8.0, 2H, tsac), 7.29 (s, $10 \mathrm{H}, \mathrm{Ph}), 4.58\left(\mathrm{bs}, 4 \mathrm{H}, 2 \mathrm{NH}_{2}\right), 3.69\left(\mathrm{~s}, 4 \mathrm{H}, 2 \mathrm{CH}_{2}\right) \mathrm{ppm}$.

\section{Synthesis of 4}

A solution of Nabit $(0.048 \mathrm{~g}, 0.28 \mathrm{mmol})$ in $\mathrm{MeOH}$ $\left(5 \mathrm{~cm}^{3}\right)$ was added to a solution of $1(0.055 \mathrm{~g}, 0.14 \mathrm{mmol})$ in $\mathrm{MeOH}\left(10 \mathrm{~cm}^{3}\right)$ and stirred for $3 \mathrm{~h}$ at room temperature to give a yellow-brown solution. The solution was filtered and left to evaporate to afford yellow crystals. These were collected by filtration, washed with water and dried in a vacuum oven. Yield $0.075 \mathrm{~g}, 87 \%$. Anal. Calc. for $\mathrm{C}_{28} \mathrm{H}_{26} \mathrm{~N}_{4} \mathrm{O}_{2} \mathrm{PdS}_{2}$ : C, 53.3, H, 4.1, N, 9.2. Found: C, 53.4, $\mathrm{H}, 4.4, \mathrm{~N}, 9.5$. Molar conductivity (DMSO): $0.80\left(\Omega^{-1}\right.$ $\left.\mathrm{mol}^{-1} \mathrm{~cm}^{-1}\right)$. IR (KBr): 3195w, 3112w, 2927w, 1650s, 1539s, 1450m, 1290m, 1155m, 459w, 342 $\mathrm{m} \mathrm{cm}^{-1} .{ }^{1} \mathrm{H}$ NMR (DMSO-d ${ }^{6}$ ): $\delta 7.76$ ppm (d, J 7.7, 2H, bit), 7.66 (d, J 7.7, 2H, bit), 7.57-7.23 (m, 14H, Ph + bit), $5.56(\mathrm{~s}, 4 \mathrm{H}$, $2 \mathrm{NH}_{2}$ ), 3.56 (s, $\left.4 \mathrm{H}, 2 \mathrm{CH}_{2}\right)$ ppm. Mp: $208-210{ }^{\circ} \mathrm{C}$.

\section{X-ray crystallography}

Crystals of cis-[Pd(bit $\left.)_{2}\left(\mathrm{H}_{2} \mathrm{NBz}\right)_{2}\right]$ (4) suitable for X-ray crystallography were produced by slow evaporation of a methanol solution. A yellow crystal with approximate dimensions $0.10 \times 0.10 \times 0.10 \mathrm{~mm}^{3}$ was mounted on a glass fibre, and all geometric and intensity data were taken from this sample using a STOE-IPDS diffractometer with Mo- $K \alpha$ radiation $(\lambda=0.7103 \AA$, graphite monochromator). Absorption corrections were made using the IPDS software package [29]. All structures were solved by direct methods and refined using full-matrix least-square routines against $F^{2}$ with SHELXL-97 [30]. Non-hydrogen atoms were refined with anisotropic displacement parameters. Hydrogen atoms were included in the models by calculating the positions (riding model) and refined with calculated isotropic displacement parameters. Illustrations were generated using DIAMOND 3.0 [31].

\section{Results and discussion}

Addition of two equivalents of sodium saccharinate to a methanol solution of trans $-\left[\mathrm{PdCl}_{2}\left(\mathrm{H}_{2} \mathrm{NBz}\right)_{2}\right]$ (1) resulted in the slow formation of trans-[Pd(N-Sac $\left.)_{2}\left(\mathrm{H}_{2} \mathrm{NBz}\right)_{2}\right]$ (2) isolated in $73 \%$ yield as a yellow solid (Scheme 1). Elemental analysis supports the substitution of both halides in $\mathbf{1}$, as does the symmetrical nature of the ${ }^{1} \mathrm{H}$ NMR spectrum. This simple substitution and formation of the trans-saccharinate complexes mirrors behaviour previously noted by us [17, 18] and others [13]. Reaction of $\mathbf{1}$ with thiosaccharin in methanol at $30{ }^{\circ} \mathrm{C}$ resulted in formation of trans$\left[\mathrm{Pd}(\mathrm{S} \text {-tsac })_{2}\left(\mathrm{H}_{2} \mathrm{NBz}\right)_{2}\right](3)$ as a yellow-orange solid in $75 \%$ yield (Scheme). Elemental analysis was indicative of the substitution of both chlorides, and this is consistent with 


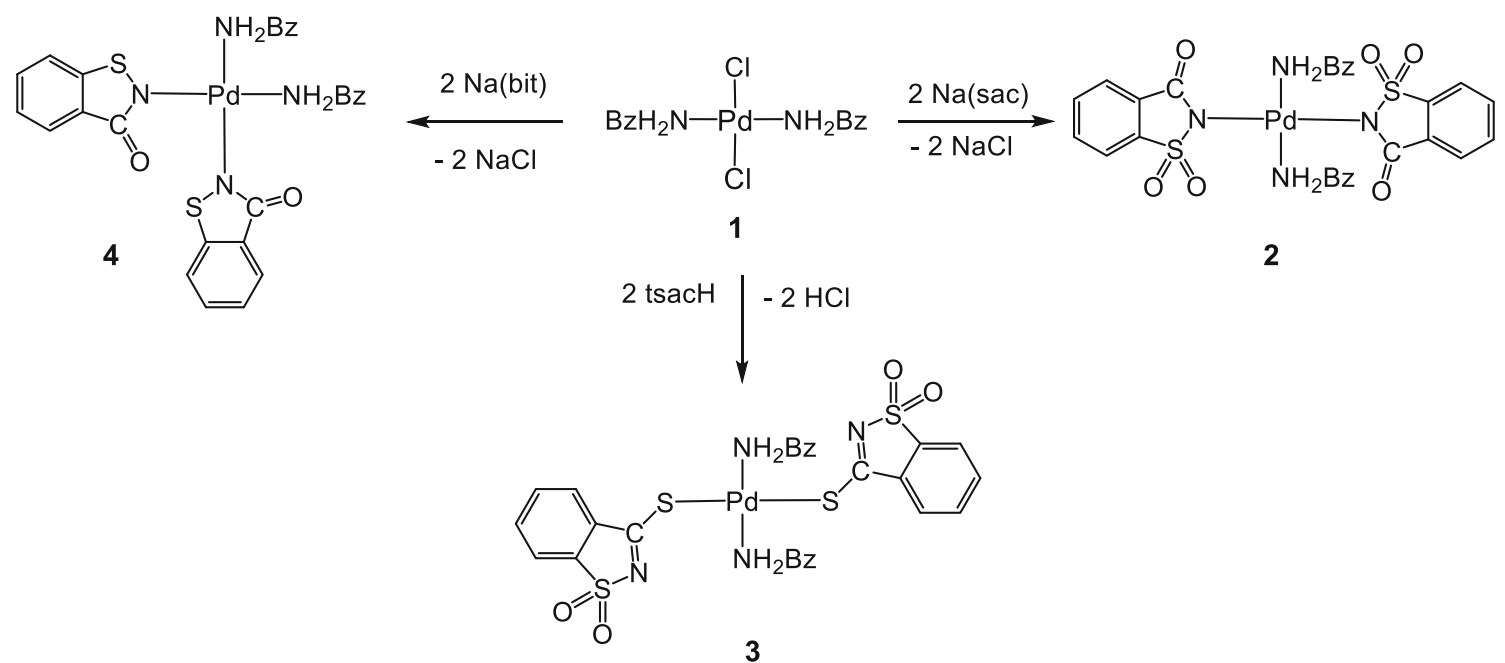

Scheme 1 Reactions of trans- $\left[\mathrm{PdCl}_{2}\left(\mathrm{H}_{2} \mathrm{NBz}\right)_{2}\right]$ (1) with two equivalents of $\mathrm{Na}(\mathrm{sac})$, tsacH and $\mathrm{Na}$ (bit)

the ${ }^{1} \mathrm{H}$ NMR spectrum. On the basis of the observation of an IR band at $1004 \mathrm{~cm}^{-1}$, which is attributed to the C-S vibration and is shifted some $35 \mathrm{~cm}^{-1}$ from the corresponding vibration in thiosaccharin, we propose that binding of the tsac ligands occurs through sulphur. This is not unexpected and is in accord with the established chalcogenophilic nature of $\operatorname{Pd}(\mathrm{II})$ and also with previous work from our laboratory [18]. While we have been unable to crystallographically characterise $\mathbf{2}$ and $\mathbf{3}$, we strongly believe that the trans arrangement confirmed in $\mathbf{1}$ is maintained upon chloride substitution. The basis of this is the relatively simple nature of their IR spectra and the aromatic region of the ${ }^{1} \mathrm{H}$ NMR spectra, both being consistent with retention of the (approximate) $D_{2 \mathrm{~h}}$ symmetry.
Fig. 2 Molecular structure of cis-[Pd(N-bit $\left.)_{2}\left(\mathrm{H}_{2} \mathrm{NBz}\right)_{2}\right](4)$ with selected bond lengths $(\AA)$ and angles $\left({ }^{\circ}\right)$ : $\mathrm{Pd}-\mathrm{N}(1)$ 2.022(2), $\mathrm{Pd}-\mathrm{N}(2) 2.015(3), \mathrm{Pd}-$ $\mathrm{N}(3)$ 2.045(2), Pd-N(4) 2.056(3), N(1)-Pd-N(2) 90.3(1), N(3)-Pd-N(4) 90.1(1), $\mathrm{N}(1)-\mathrm{Pd}-\mathrm{N}(3)$ 178.5(1), N(2)Pd-N(4) 177.8(1)

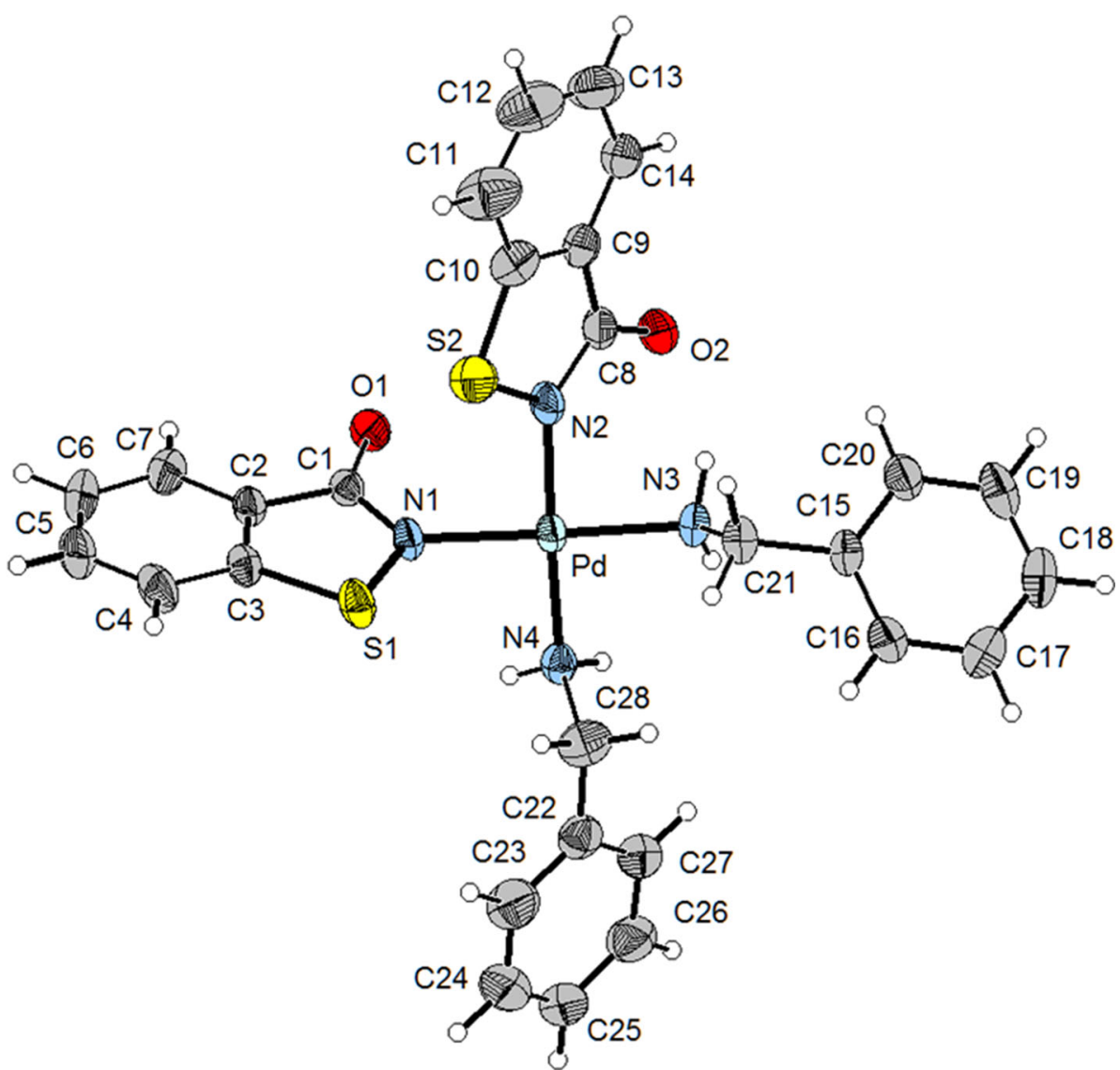


Table 1 Crystallographic data for cis-[Pd(bit $\left.)_{2}\left(\mathrm{H}_{2} \mathrm{NBz}\right)_{2}\right](\mathbf{4})$

\begin{tabular}{ll}
\hline Empirical formula & $\mathrm{C}_{28} \mathrm{H}_{26} \mathrm{~N}_{4} \mathrm{O}_{2} \mathrm{Pd} \mathrm{S}_{2}$ \\
Formula weight & 621.05 \\
Temperature & $200(2) \mathrm{K}$ \\
Wavelength & $0.71073 \AA$ \\
Crystal system, space group & Monoclinic, $P 2_{1} / \mathrm{c}$ \\
Unit cell dimensions & $a=9.8581(4) \AA, \alpha=90^{\circ}$ \\
& $b=23.7295(8) \AA, \beta=102.856(3)^{\circ}$ \\
& $c=11.6318(5) \AA, \gamma=90^{\circ}$ \\
Volume & $2652.79(18) \AA^{3}$ \\
$Z$, Calculated density & $4,1.555 \mathrm{mg} / \mathrm{m}^{3}$ \\
Absorption coefficient & $0.890 \mathrm{~mm}{ }^{-1}$ \\
F(000) & 1264 \\
Crystal size & $0.10 \times 0.10 \times 0.10 \mathrm{~mm}$ \\
Theta range for data collection & $1.72-29.30^{\circ}$ \\
Limiting indices & $-13 \leq h \leq 13,-32 \leq k \leq 32,-15 \leq 1 \leq 14$ \\
Reflections collected/unique & $19,921 / 7115[R(\mathrm{int})=0.0597]$ \\
Completeness to $\theta=25.00$ & $97.9 \%$ \\
Max. and min. transmission & 0.9162 and 0.9162 \\
Refinement method & Full-matrix least-squares on $F^{2}$ \\
Data/restraints/parameters & $7115 / 0 / 350$ \\
Goodness-of-fit on $F^{2}$ & 1.052 \\
Final $R$ indices $[I>2$ sigma $(I)]$ & $R_{1}=0.0377, \mathrm{w} R_{2}=0.0732$ \\
$R$ indices (all data) & $R_{1}=0.0696, \mathrm{w} R_{2}=0.0851$ \\
Largest diff. peak and hole & 0.605 and -0.628 e A ${ }^{-3}$ \\
\hline &
\end{tabular}

This assignment is also made on the basis of the chemical shifts of the amine protons at $\delta 4.34$ and 4.58, respectively (see below).

Reaction of two equivalents of sodium benzisothiozolinate with $\mathbf{1}$ in methanol gave a yellow-brown solution and, unlike previous reactions with sodium saccharinate and thiosaccharin, no solids initially precipitated from the solution. However, after filtration and upon standing for a few days, slow evaporation of the methanol led to the growth of yellow crystals identified as cis-[Pd(N-bit $\left.)_{2}\left(\mathrm{H}_{2} \mathrm{NBz}\right)_{2}\right]$ (4) in $87 \%$ yield. The ${ }^{1} \mathrm{H}$ NMR spectrum was significantly different to those of 1-3, being more complicated with overlapping signals in the aromatic region (indicative of a lowering of the $\mathrm{D}_{2 \mathrm{~h}}$ symmetry), while the amine protons appeared at $\delta$ 5.56. We have recently reported $\left[\mathrm{Pd}\left(\mathrm{H}_{2} \mathrm{NBz}\right)_{3} \mathrm{Cl}\right][\mathrm{Cl}]$ and note that its ${ }^{1} \mathrm{H} \mathrm{NMR}$ spectrum shows two amine resonances in an approximate $2: 1$ ratio at $\delta$ $4.70(4 \mathrm{H})$ and $5.26(2 \mathrm{H})$ [34] assigned to the mutual trans amines and that lying trans to the chloride, respectively. This suggested to us that the amines in $\mathbf{4}$ adopted a relative cis orientation. A single-crystal analysis was carried out in order to determine the coordination mode of the bit ligands and relative arrangement of amines. The results of this are shown in Fig. 2 and its caption (Table 1).

The structure confirms that the two bit ligands bind in a monodentate fashion through nitrogen, but the main surprise was their relative cis arrangement. All four palladium-nitrogen bond lengths are similar, although those to the benzisothiazolinate ligands $[\mathrm{Pd}-\mathrm{N}(1)$ 2.022(2), $\mathrm{Pd}-$ $\mathrm{N}(2) 2.015(3) \AA]$ are slightly shorter than to the benzylamine groups [Pd-N(3) 2.045(2), Pd-N(4) 2.056(3) ̊]. The latter compare well with the related bonds in trans$\left[\mathrm{PdCl}_{2}\left(\mathrm{H}_{2} \mathrm{NBz}\right)_{2}\right][\mathrm{Pd}-\mathrm{N} 2.050(4)$ and 2.046(2) $\AA$ ] [32, 33] and $\left[\mathrm{PdCl}\left(\mathrm{H}_{2} \mathrm{NBz}\right)_{3}\right] \mathrm{Cl} . \mathrm{H}_{2} \mathrm{O}[\mathrm{Pd}(1)-\mathrm{N}(1) 2.061(2), \mathrm{Pd}(1)-$ $\mathrm{N}(2)$ 2.053(2), Pd(1)-N(3) 2.063(2) ̊] [34]. Both Pd$\mathrm{N}$ (bit) bond lengths in $\mathbf{4}$ are significantly shorter than those in $\left[\mathrm{Pd}(\mathrm{N}-\text { bit })_{2}\left(\kappa^{2}-\mathrm{Ph}_{2} \mathrm{PCH}_{2} \mathrm{CH}_{2} \mathrm{PPh}_{2}\right)\right][\mathrm{Pd}-\mathrm{N} 2.070(3) \&$ $2.100(3) \AA]$ [26], being closer to $\left[\mathrm{Pd}(\mathrm{N}-\mathrm{bit})_{2}\left(\kappa^{2}-\mathrm{H}_{2} \mathrm{NCH}_{2}\right.\right.$ $\left.\mathrm{CH}_{2} \mathrm{NH}_{2}\right)$ ] [Pd-N 2.029(2) \& 2.031(2) ̊] [25], suggesting that they may be sensitive to a trans-influence.

Complex 4 is the third example of a palladiumbis(benzisothiozolinate) complex, and like the diphosphine and diamine derivatives, it also contains a cis arrangement of benzisothiazolinate ligands. Thus, it may be that these ligands inherently prefer to adopt a relative cis orientation, although in $\mathbf{4}$ this is the first example where the arrangement is not imposed by a chelating co-ligand. A possible explanation for the cis geometry in $\mathbf{4}$ comes from inspection of the intermolecular packing of the individual molecules. Thus, as shown in Fig. 3, pairs of molecules are strongly associated by hydrogen bonds between the amine protons and the oxygen atoms of the benzisothiazolinate 
Fig. 3 Packing of two molecules of $\mathbf{4}$ with intermolecular bond lengths

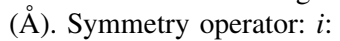
$-x+2,-y,-z$. We located the protons on nitrogen from Fourier difference maps and acknowledge that this leads to abnormally short $\mathrm{N}-\mathrm{H}$ distances but we favour this approach over that of using computationally generated positions.

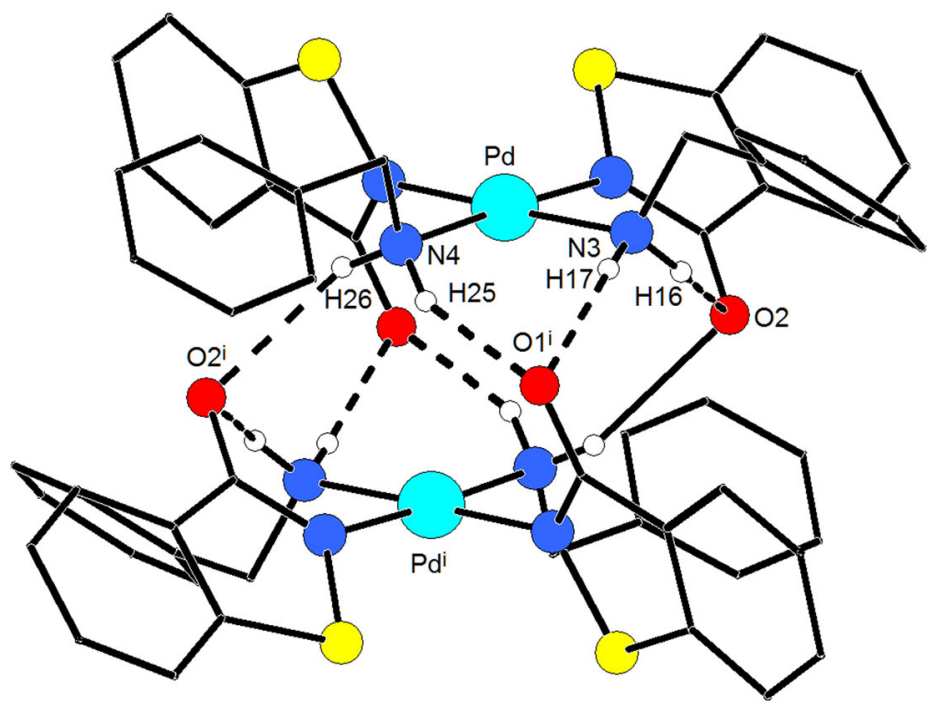

\begin{tabular}{|l|l|l|l|l|}
\hline & $\mathrm{D}-\mathrm{H} / \AA$ & $\mathrm{H} \ldots \mathrm{A} / \AA$ & $\mathrm{D} \ldots \mathrm{A} / \AA$ & $<(\mathrm{DHA}) /^{\circ}$ \\
\hline $\mathrm{N} 3-\mathrm{H} 16 \cdots \mathrm{O} 2$ & $0.97(3)$ & $1.95(3)$ & $2.826(4)$ & $150(2)$ \\
\hline $\mathrm{N} 3-\mathrm{H} 17 \cdots \mathrm{O} 1^{\mathrm{i}}$ & $0.82(3)$ & $2.02(3)$ & $2.813(3)$ & $162(3)$ \\
\hline $\mathrm{N} 4-\mathrm{H} 25 \cdots \mathrm{O} 1^{\mathrm{i}}$ & $0.78(4)$ & $2.18(4)$ & $2.882(3)$ & $151(3)$ \\
\hline $\mathrm{N} 4-\mathrm{H} 26 \cdots \mathrm{O} 2^{\mathrm{i}}$ & $0.76(4)$ & $2.45(4)$ & $3.102(3)$ & $145(4)$ \\
\hline
\end{tabular}

ligands. This arrangement brings the two palladium atoms in close proximity [Pd....Pd $3.839 \AA$ A ].

\section{Conclusion}

In this contribution, we have shown that simple exchange of both chlorides in trans-[ $\left.\mathrm{PdCl}_{2}\left(\mathrm{H}_{2} \mathrm{NBz}\right)_{2}\right]$ (1) for the related mono-anionic (X) N-heterocyclic saccharinate, thiosaccharinate and benzisothiozolinate ligands in all cases affords the expected palladium(II) complexes $\left[\mathrm{PdX}{ }_{2}\left(\mathrm{H}_{2} \mathrm{NBz}\right)_{2}\right]$. The molecular structure of the product is, however, sensitive to the nature of the incoming ligand with products trans- $\left[\mathrm{Pd}(\mathrm{N}-\mathrm{sac})_{2}\left(\mathrm{H}_{2} \mathrm{NBz}\right)_{2}\right]$ (2), trans$\left[\mathrm{Pd}(\mathrm{S}-\mathrm{tsac})_{2}\left(\mathrm{H}_{2} \mathrm{NBz}\right)_{2}\right]$ (3) and cis-[Pd(N-bit $\left.)_{2}\left(\mathrm{H}_{2} \mathrm{NBz}\right)_{2}\right]$ (4) resulting, respectively. Formation of $\mathrm{N}$-coordinated saccharinate and S-bound thiosaccharinate ligands to the same metal fragments has been previously noted [18] and likely results from a preference of Pd(II) to bind to a soft sulphur centre when available. Palladium(II) bis(benzisothiozolinate) complexes are far less common [25, 26] but the three crystallographically characterised examples all contain a cis arrangement of benzisothiozolinate ligands. In $\left[\mathrm{Pd}(\mathrm{N}-b i t)_{2}\left(\mathrm{H}_{2} \mathrm{NBz}\right)_{2}\right](4)$, this is the first time that this cis arrangement has not been imposed by the presence of a chelating co-ligand and the preferential precipitation of cis-4 over its trans isomer (which may be initially formed) may result from the ability of the cis complex to form strong intermolecular hydrogen bonds with a neighbour, thus favouring crystallisation of this isomer.

\section{Supplementary information}

CCDC 1503153 contains the supplementary crystallographic data for 4. These data can be obtained free of charge from the Cambridge Crystallographic Data Center via www.ccdc.cam.ac.uk/data-request/cif.

Acknowledgements We would like to thank the University of Tikrit for partial support of this work.

Open Access This article is distributed under the terms of the Creative Commons Attribution 4.0 International License (http://crea tivecommons.org/licenses/by/4.0/), which permits unrestricted use, distribution, and reproduction in any medium, provided you give appropriate credit to the original author(s) and the source, provide a link to the Creative Commons license, and indicate if changes were made.

\section{References}

1. Baran EJ, Yilmaz VT (2006) Coord Chem Rev 250:1980

2. Baran EJ (2005) Quim Nova 28:326 
3. Henderson W, Nicholson BK, McCaffery LJ (1999) Inorg Chim Acta $285: 145$

4. Henderson W, Nicholson BK, Chung DC (2002) Acta Cryst. E58:m432

5. Santana MD, García-Bueno R, García G, Sánchez G, García J, Kapdi AR, Naik M, Pednekar S, Pérez J, García L, Pérez E, Serrano JL (2012) Dalton Trans 41:3832

6. Vieites M, Gambino D, Gonzalez M, Cerecetto H, Tarulli SH, Quinzani OV, Baran EJ (2006) J Coord Chem 59:101

7. Tarulli SH, Quinzani OV, Mandolesi SD, Guida JA, Echeverria GV, Piro OE, Castellano EE, Anorg Z (2009) Allg. Chem. 465:1604

8. Guney E, Yilmaz VT, Kazak C (2010) Polyhedron 29:1285

9. Guney E, Yilmaz VT, Sengul A, Buyukgunor O (2010) Inorg Chim Acta 363:438

10. Guney E, Yilmaz VT, Ari F, Buyukgungor O, Ulukaya E (2011) Polyhedron 30:114

11. Guney E, Yilmaz VT, Buyukgungor O (2010) Inorg Chim Acta 363:2416

12. Guney E, Yilmaz VT, Buyukgungor O (2011) Polyhedron 30:1968

13. Yilmaz VT, Ertem A, Guney E, Buyukgungor O, Anorg Z (2010) Allg Chem 636:610

14. Kaya Y, Yilmaz VT, Gumus S (2011) Spectrochim Acta A Mol Biomol Spect 79:1171

15. Al-Jibori SA, Al-Nassiry AIA, Hogarth G, Salassa L (2013) Inorg Chim Acta 398:46

16. Al-Jibori SA, Al-Jibori MHS, Hogarth G (2013) Inorg Chim Acta 398:117

17. Al-Jibori SA, Habeeb AT, Al-Jibori GHH, Dayaaf NA, Merzweiler K, Wagner C, Schmidt H, Hogarth G (2014) Polyhedron $67: 338$
18. Al-Jibori SA, Al-Jibori QKA, Schmidt H, Merzweiler K, Wagner C, Hogarth G (2013) Inorg Chim Acta 402:69

19. Ulukaya E, Ari F, Dimas K, Ikitimur EI, Guney E, Yilmaz VT (2011) Eur J Med Chem 46:4957

20. Ari F, Ulukaya E, Sarimahut M, Yilmaz VT (2013) Bioorg Med Chem 21:3016

21. Ari F, Aztopal N, Icsel C, Yilmaz VT, Guney E, Buyukgungor O, Ulukaya E (2013) Bioorg. Med. Chem. 21:6427

22. Icsel C, Yilmaz VT (2013) DNA Cell Biol 32:165

23. Al-Jibori SA, Al-Jibori GH, Al-Hayaly LJ, Wagner C, Schmidt H, Timur S, Barlas FB, Subasi E, Ghosh S, Hogarth G (2014) J Inorg Biochem 141:55

24. Al-Jibori SA, Al-Nassiry RAQ, Al-Jibori GHH, Merzweiler K, Wagner C, Schmidt H, Basak-Modi S, Hogarth G (2014) Trans. Met. Chem. 39:735

25. Griffith DM, Haughey A, Chahal S, Muller-Bunz H, Marmion CJ (2010) Inorg Chim Acta 363:2333

26. Al-Jibori SA, Ahmed BSM, Ahmed SA, Karadağ A, Schmidt H, Wagner C, Hogarth G (2015) Inorg Chim Acta 436:7

27. Meadow JR, Cavaguol JC (1951) J Org Chem 16:1582

28. Cope AC, Friedrich EC (1968) J Am Chem Soc 90:909

29. IPDS-Software Package, Stoe and Cie (1999)

30. Sheldrick GM (1997) SHELXS-97. Program for Refinement of Crystal Structures, Göttingen

31. Brandenburg K (2014) Diamond 3.2k, crystal impact. GbR, Bonn

32. Decken A, Pisegna GL, Vogels CM, Westcott SA (2000) Acta Cryst. C56:1071

33. Sui-Seng C, Zargarian D (2003) Acta Cryst. E59:m957

34. Al-Jibori SA, Hameed WJ, Al-Hayaly LJ, Basak-Modi S, Hogarth G (2015) Inorg Chem Commun 62:91 